\title{
BIOTECHNOLOGICAL POTENTIAL OF PSEUDOKIRCHNERIELLA SUBCAPITATA, SCENEDESMUS SPINOSUS, AND SCENEDESMUS ACUMINATUS
}

\author{
V.M. Nascimento, K.M. Nascimento and G.G. Fonseca* \\ Laboratory of Bioengineering, Faculty of Biological and Environmental Sciences, CEP 79.804-970, \\ Federal University of Grande Dourados, Dourados - MS, Brazil
}

(Received: 22 August 2019; accepted: 15 January 2020)

\begin{abstract}
Microalgae are promising alternatives to sequestration of carbon and reduction of environmental problems, e.g. the greenhouse effect and industrial water pollution. Depending on the growth conditions, microalgae can differ in their metabolism products, leading them to grow at different rates. Intracellular reactions and nutritional requirements from cell metabolism, as well as biomass composition, may vary in function of the temperature. In this study, the biotechnological potential of three microalgae strains from the species was evaluated in terms of growth, biomass composition, fatty acid profile, and chlorophyll and carotenoids contents. Each of the three species demonstrated different potential depending on their metabolisms: Scenedesmus spinosus presented fastest growth and had the highest protein content (52.99\%), Pseudokirchneriella subcapitata presented the highest content of lipid extracted (26.51\%), and Scenedesmus acuminatus showed increased production of chlorophyll $\left(5.25 \mathrm{mg} \mathrm{l}^{-1}\right)$ and carotenoid $\left(1.02 \mathrm{mg} \mathrm{l}^{-1}\right)$ pigments.
\end{abstract}

Keywords: microalgae, kinetics, growth, composition, pigments, fatty acids

Microalgae are unicellular organisms of rapid growth. They are found in marine environment, freshwater, and soil. They have the potential to reduce emerging environmental problems, e.g. greenhouse effect and water pollution (HARUN et al., 2010). The number of species of these organisms is not known exactly. However, the existence of 200000 to several million of representatives of this group is estimated. This diversity is also reflected in their biochemical composition and their unlimited source of bioproducts (COÊLHO et al., 2019).

Beyond the biofixation of $\mathrm{CO}_{2}$ from the atmosphere, the biomass formed by microalgae can be used as sources of chlorophyll, fatty acids, tocopherols, sterols, proteins, carbohydrates, vitamins, minerals, antioxidants, and pigments (KISS \& NÉMETH, 2019), for the production of biofuels, e.g. biodiesel, biogas, bioethanol and hydrogen, organic fertilizer, natural dyes, pharmaceutical compounds, and nutrients for animal feed or even human food (RIBEIRO et al., 2019).

Some fatty acids synthesized by microalgae, e.g. $\omega-3$ and $\omega-6$, are important in food and pharmaceutical industries, as they are the main precursors of hormones, e.g. prostaglandins, prostacyclins, leukotrienes, and thromboxanes (PEREIRA et al., 2012). In addition, three main groups of pigments are found in their biomass: chlorophylls, carotenoids, and phycobilins. Carotenoids are the pigments of greater commercial interest. Some strains can accumulate high concentrations of $\beta$-carotene, astaxanthin, or canthaxanthin, which have a wide application, e.g. dyes and natural antioxidants (KISS \& NÉMETH, 2019). Chlorophyll has antioxidant properties and high antimutagenic activity. Under ideal growth conditions,

* To whom correspondence should be addressed.

Phone: +55 67 3410-2227; fax: +55 67 3410-2190; e-mail: ggf@ufgd.edu.br

0139-3006 @ 2020 Akadémiai Kiadó, Budapest 
microalgae can accumulate about $4 \%$ of chlorophyll in dry weight. The species of green microalgae mostly have chlorophyll a and b (HARUN et al., 2010).

The microalgae studied here have been extensively investigated for their role in production of biofuel (NASCIMENTO et al., 2013, Dhup et al., 2016) and environmental protection (Minillo et al., 2013). However, few studies underline other biotechnological potentialities. Thus, the aim of this work was to evaluate the biotechnological potential of three microalgae strains from the species Pseudokirchneriella subcapitata, Scenedesmus spinosus, and Scenedesmus acuminatus, in terms of growth, biomass composition, fatty acid profile, and chlorophyll and carotenoids contents.

\section{Materials and methods}

\subsection{Microorganisms, isolation, and preservation}

Pseudokirchneriella subcapitata (Korshikov) Hindak (Chlorophyceae) was obtained from the Laboratory of Limnology, from the Federal University of São Carlos. It has been isolated from the Broa Dam (São Carlos, Brazil). Scenedesmus spinosus Chodat and Scenedesmus acuminatus (Lagerheim) Chodat were previously isolated by MiNILLO and co-workers (2013).

The cultures were maintained in synthetic medium (Chu-12) at $25^{\circ} \mathrm{C}, 1 \mathrm{kLux}$ light, 12 $\mathrm{h}$ photoperiod, and constant stirring in a BOD incubator (200 r.p.m.) (MinILLo et al., 2013). This medium contained per litre of distilled water: $\mathrm{Ca}\left(\mathrm{NO}_{3}\right)_{2}, 0.03 \mathrm{~g}$; $\mathrm{K}_{2} \mathrm{HPO}_{4}, 0.005 \mathrm{~g}$; $\mathrm{MgSO}_{4} \cdot 7 \mathrm{H}_{2} \mathrm{O}, 0.075 \mathrm{~g} ; \mathrm{K}_{2} \mathrm{SiO}_{3}, 0.025 \mathrm{~g} ; \mathrm{KCl}, 0.005 \mathrm{~g} ; \mathrm{Na}_{2} \mathrm{CO}_{3}, 0.02 \mathrm{~g} ; \mathrm{FeCl}_{3}, 0.0005 \mathrm{~g}$; autoclaved $\left(121^{\circ} \mathrm{C}, 20 \mathrm{~min}\right)$ (SIPAÚBA-TAVARES et al., 1999).

\subsection{Cultivations}

Main cultivations were carried out in static 51 Erlenmeyer flasks containing 4.51 synthetic medium (Chu-12). Agitation was supplied by aeration. Cultivations started by the addition of microalgae inoculum with optical density (OD) of $2(\lambda=670 \mathrm{~nm})$ in the concentration of $1 \%$ $(45 \mathrm{ml}$ ) of the useful volume of the flask (corresponding to an initial cell density of $0.06 \pm 0.03$ $\mathrm{g}^{-1}$ ). Each treatment was represented by a single strain, which was cultivated in triplicate during 33 days in a BOD incubator at $25 \pm 1.0^{\circ} \mathrm{C}$, light intensity of $1.5 \mathrm{kLux}, 12 \mathrm{~h}$ photoperiods, with filtered air provided at a flow rate of $0.451 \mathrm{~min}^{-1}$ through aquarium pumps.

Samplings were carried out at intervals of 3 days until stationary growth phase. Algae growth and $\mathrm{pH}$ were monitored. The biomass formation was monitored by OD of the cultures at $670 \mathrm{~nm}$ in a UV-Vis spectrophotometer, which was correlated to dry weight via a standard curve previously constructed.

\subsection{Biomass concentration}

The biomass pellet was obtained after centrifugation (1100 r.p.m., 10 min.) and drying in oven $\left(70^{\circ} \mathrm{C}\right)$ until constant weight.

The dried cell mass $\left(\mathrm{X}, \mathrm{g}^{-1}\right)$ was determined by the quotient of the difference of weight by the volume of centrifuged medium. It was also indirectly determined via OD measurements performed with a spectrophotometer at $670 \mathrm{~nm}$. For this purpose, the measured absorbance values were converted into mass values using a linear relationship determined for each experiment. 


\subsection{Biomass composition}

Moisture, crude protein, and crude ash contents were determined in triplicate according to the methods described by AOAC (2000). Moisture was determined by the oven drying method at $105{ }^{\circ} \mathrm{C}$ until constant weight (method 950.46), protein by the Kjeldhal method (method 928.08 ) using a 6.25 factor to convert the nitrogen content into crude protein, and ash by using the muffle oven technique (method 920.153). Total lipid content was determined in triplicate according to BLIGH and DYER (1959). Carbohydrates were estimated by difference.

\subsection{Determination of fatty acids composition}

The fatty acid methyl esters (FAME) were identified in a gas chromatograph equipped with an HP-88 column $(60 \mathrm{~m} \times 0.250 \mathrm{~mm} \times 0.20 \mu \mathrm{m})$. Analysis was conducted under the following conditions: carrier gas helium $\left(1 \mathrm{ml} \mathrm{min}{ }^{-1}\right)$ (split 1:50); injector and detector temperatures of $260{ }^{\circ} \mathrm{C}$; detection system was flame ionization detector (FID), with the oven set at $140{ }^{\circ} \mathrm{C}$ for $5 \mathrm{~min}$, with a temperature increase up to $240{ }^{\circ} \mathrm{C}$ at $4{ }^{\circ} \mathrm{C} \mathrm{min}{ }^{-1}$, thereafter maintained at 240 ${ }^{\circ} \mathrm{C}$ for $5 \mathrm{~min}$. FAMEs were identified by comparing the retention time of the constituents of the sample with a mixture of FAME standards and quantified by the area normalization method (AOCS, 2005).

\subsection{Determination of chlorophyll}

Chlorophyll was extracted by organic solvent until the biomass appeared colourless, and its concentration was determined by spectrophotometry (LEE \& SHEN, 2004). Equations and $\lambda$ (649 and $665 \mathrm{~nm})$ were modified due to changing the solvent for ethanol $95 \%\left(\mathrm{v} \mathrm{v}^{-1}\right)$ (LichtentHALER \& WellbuRn, 1983).

\subsection{Determination of kinetic parameters}

The exponential growth phase (EGP) was identified as the linear region on an $\ln (\mathrm{OD})$ vs. time plot for batch cultivation data. The maximal specific growth rate $\left(\mu_{\max }\right.$, day $\left.^{-1}\right)$ was determined as the slope of the linear region and the doubling time (DT, days) by the ratio of $\ln (2)$ and $\mu_{\max }$. The maximum biomass concentration $\left(\mathrm{X}_{\max }, \mathrm{g} \mathrm{l}^{-1}\right)$ was indicated by the maximum dried cell mass concentration or OD observed in each experiment. The maximum cell productivity $\left(\mathrm{P}_{\text {cell }}, \mathrm{g} \mathrm{l}^{-1}\right.$ day $\left.^{-1}\right)$ was obtained according to the equation $\mathrm{P}_{\text {cell }}=\left(\mathrm{X}_{\max }-\mathrm{X}_{0}\right) /$ $\left(\mathrm{t}-\mathrm{t}_{0}\right)$, where $\mathrm{X}_{0}$ is the biomass concentration $\left(\mathrm{g} \mathrm{l}^{-1}\right)$ at initial time $\left(\mathrm{t}_{0}\right.$, day zero) and $\mathrm{t}$ the time (days) corresponding to $X_{\max }$ (RIBEIRo et al. 2019). The same was carried out for the maximum carotenoids productivity $\left(\mathrm{P}_{\mathrm{C}}, \mathrm{mg} \mathrm{l}^{-1}\right.$ day $\left.^{-1}\right)$ and maximum ethereal extract productivity $\left(\mathrm{P}_{\mathrm{Ee}}, \mathrm{g}\right.$ $1^{-1}$ day $\left.^{-1}\right)$.

\section{Results and discussion}

Table 1 shows the cultivation parameters obtained in this study of microalgae cultivated in synthetic medium (Chu-12) under a photoperiod of $12 \mathrm{~h}$ light/dark. Growth and $\mathrm{pH}$ kinetics for P. subcapitata, S. spinosus, and S. acuminatus cultivations can be observed in Figs. 1, 2, and 3 , respectively. For all studied strains $\mathrm{pH}$ remained within the range 7.8 to 8.3 ; increasing gradually during cell growth. 
Table 1. Cultivation parameters of the microalgae P. subcapitata, S. spinosus, and S. acuminatus grown in the synthetic culture medium Chu-12

\begin{tabular}{lccc}
\hline Parameters & Species & \\
& P. subcapitata & S. spinosus & S. acuminatus \\
\hline Cultivation (days) & 42 & 33 & 51 \\
$\mu_{\max }\left(\right.$ day $\left.^{-1}\right)$ & $0.093 \pm 0.006$ & $0.170 \pm 0.021$ & $0.068 \pm 0.001$ \\
$\mathrm{DT}($ days $)$ & $7.431 \pm 0.439$ & $4.115 \pm 0.504$ & $10.25 \pm 0.130$ \\
$\mathrm{X}_{\text {max }}\left(\mathrm{g}^{-1}\right)$ & $0.754 \pm 0.024$ & $1.657 \pm 0.085$ & $1.190 \pm 0.084$ \\
$\mathrm{P}_{\text {cell }}\left(\mathrm{g} \mathrm{l}^{-1}\right.$ day $\left.^{-1}\right)$ & $0.018 \pm 0.001$ & $0.052 \pm 0.003$ & $0.024 \pm 0.001$ \\
$\mathrm{P}_{\mathrm{Ct}}\left(\mathrm{mg} \mathrm{l}^{-1}\right.$ day $\left.^{-1}\right)$ & $0.006 \pm 0.000$ & $0.009 \pm 0.001$ & $0.020 \pm 0.000$ \\
$\mathrm{P}_{\mathrm{Ee}}\left(\mathrm{g} \mathrm{l}^{-1}\right.$ day $\left.^{-1}\right)$ & $0.005 \pm 0.000$ & $0.178 \pm 0.009$ & $0.226 \pm 0.009$ \\
\hline
\end{tabular}

DT: doubling time; $\mu_{\max }$ : maximum specific growth rate; $\mathrm{X}_{\max }$ : maximum biomass concentration; $\mathrm{P}_{\text {cell }}$ : maximum cell productivity; $\mathrm{P}_{\mathrm{Ct}}$ : maximum carotenoids productivity; $\mathrm{P}_{\mathrm{Ee}}$ : maximum ethereal extract productivity

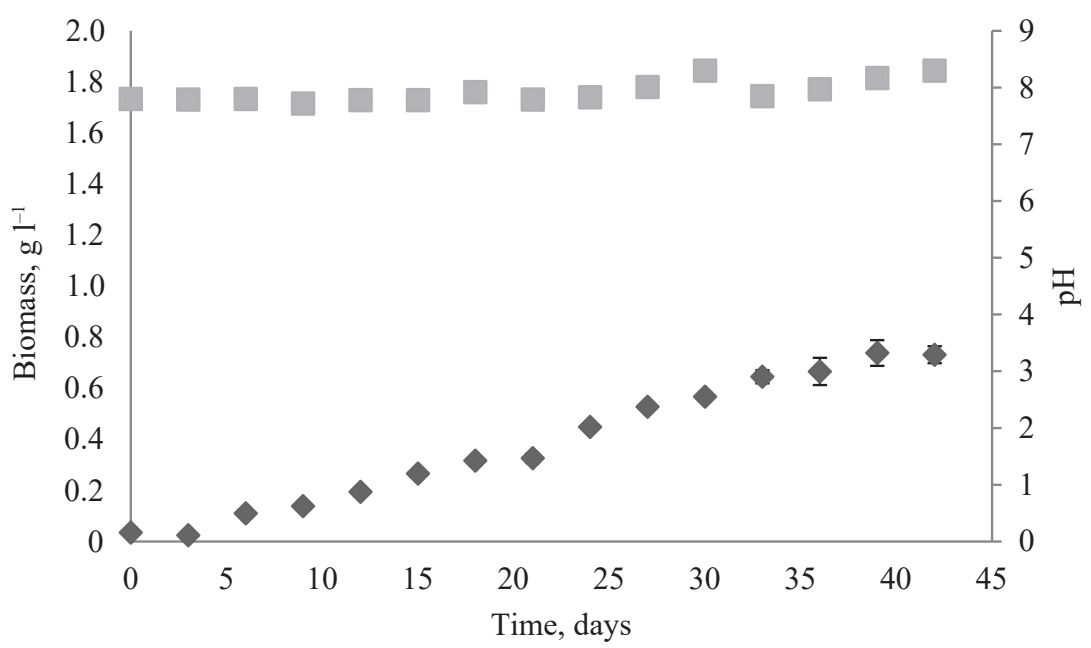

Fig. 1. Growth kinetics of P. subcapitata $\left(\Delta \mathrm{T}=26.0 \pm 3.1^{\circ} \mathrm{C}\right.$

biomass; : $: \mathrm{pH})$

In aqueous medium, the inorganic carbon may be in the form of $\mathrm{CO}_{2}, \mathrm{H}_{2} \mathrm{CO}_{3}, \mathrm{HCO}_{3}^{-}$, or $\mathrm{CO}_{3}{ }^{2-}$, and their proportions depend on $\mathrm{pH}$, whereas, according to the $\mathrm{pH}$ increase, the proportions of bicarbonates and carbonates increase in the culture medium. Thus, it is possible to admit that the demand for $\mathrm{CO}_{2}$ was similar in the experiments, as the $\mathrm{pH}$ variation (increase) was quite close between strains (Figs. 1, 2, and 3).

The lag phase indicates the period of adaptation for each species. S. spinosus presented shorter lag phase (Fig. 2) than the other species (Figs. 1 and 3). Though it took longer to get adapted, the species $S$. spinosus revealed the best growth parameters: higher $\mu_{\max }, \mathrm{X}_{\max }$, and $\mathrm{P}_{\text {cell }}$ under the studied conditions (Table 1). Because of this high $\mathrm{P}_{\text {cell }}$, and its carbon sequestration capacity, cultivation of $S$. spinosus is proposed for the mitigation of $\mathrm{CO}_{2}$ (Minillo et al., 2013). 


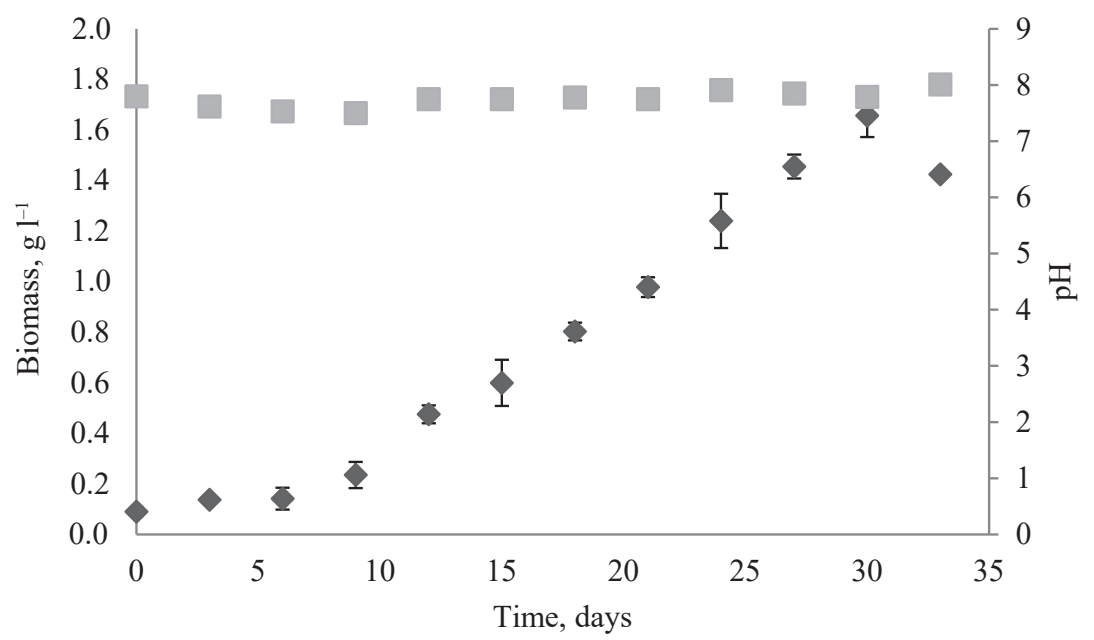

Fig. 2. Growth kinetics of $S$. spinosus $\left(\Delta \mathrm{T}=24.1 \pm 3.0^{\circ} \mathrm{C} ;>\right.$ : biomass; $\square$ : $\left.\mathrm{pH}\right)$

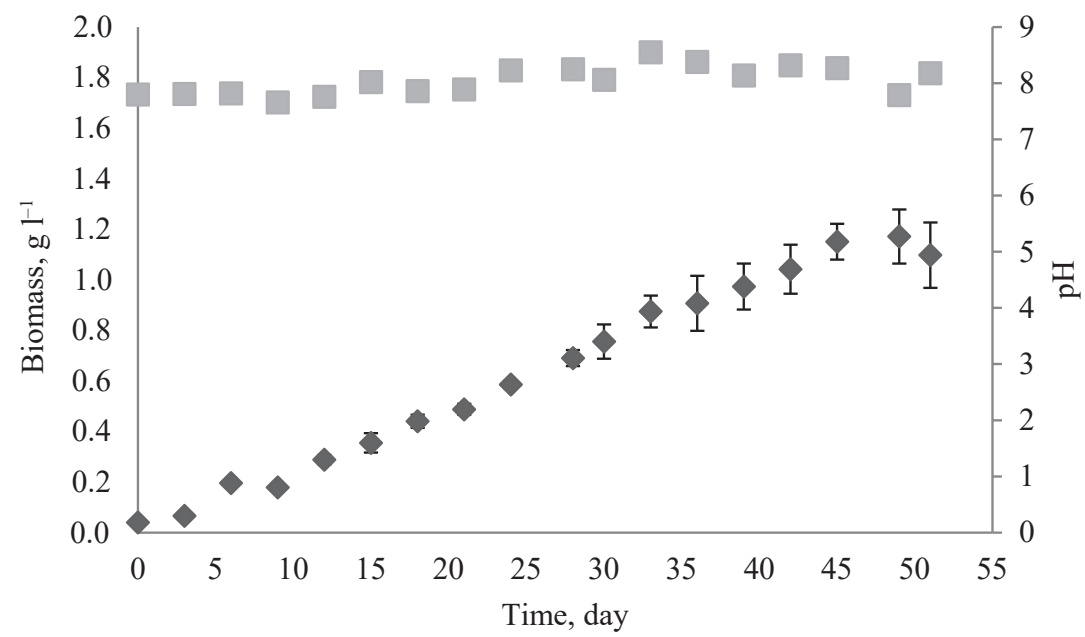

Fig. 3. Growth kinetics of $S$. acuminatus $\left(\Delta \mathrm{T}=26.6 \pm 1.5^{\circ} \mathrm{C} ;\right.$ : biomass; $\left.\square \mathrm{pH}\right)$

The proximate composition of biomass showed highest protein content for S. spinosus $(53 \%)$, revealing its potential in the enrichment of food products, for both animals and humans. A wide variety of algae have already been analysed for their biochemical composition and subjected to comprehensive nutritional and toxicological assessments demonstrating the suitability of biomass as a supplementary food or substitute for conventional animal feed sources (HARUN et al., 2010).

Among the studied species, $P$. subcapitata presented the highest content of ethereal extract (26.51\%; Table 2). The value was quite close to the $28.43 \pm 5.4 \%$ found in a previous study conducted with the same species (NASCIMENTO et al., 2013). Due to its potential, this 
species has been evaluated for biofuel production, despite the few results available (ADEYEMI et al., 2011). S. acuminatus presented considerable fat content (19\%; Table 2), which is comparable to the $17 \%$ obtained with another strain of this species, isolated in Pakistan, being considered a good oil producer (MusharRaF et al., 2012). Despite the highest $\mathrm{X}_{\max }$ observed here, the culture presented higher DT (10 days) compared to P. subcapitata (7 days) and S. spinosus (4 days) (Table 1).

The fatty acid profiles of the oils extracted from the final biomasses are shown in Table 3. The data show that the number of fatty acid compounds identified for each species is related to their lipid content, i.e. the higher the lipid accumulation is, the number of produced different fatty acids is also higher (Tables 2 and 3 ).

Table 2. Proximal composition of the dry microalgae biomasses obtained at the end of the cultivations of $P$. subcapitata, $S$. spinosus, and $S$. acuminatus grown in the synthetic culture medium Chu-12

\begin{tabular}{lcccc}
\hline Species & Protein $(\%)$ & Total lipids $(\%)$ & Ash $(\%)$ & Carbohydrates* $(\%)$ \\
\hline P. subcapitata & $41.60 \pm 0.90$ & $26.51 \pm 1.67$ & $6.61 \pm 0.04$ & 25.28 \\
S. spinosus & $52.99 \pm 0.27$ & $10.84 \pm 0.25$ & $5.37 \pm 0.04$ & 31.24 \\
S. acuminatus & $45.18 \pm 0.80$ & $19.13 \pm 0.95$ & $5.91 \pm 0.05$ & 29.79 \\
\hline
\end{tabular}

*By difference

Table 3. Fatty acid profile (\%) of the oils extracted from the biomasses and contents of chlorophyll (a and b) and carotenoids $\left(\mathrm{mg} \mathrm{l}^{-1}\right)$ from the microalgae biomasses obtained with the microalgae $P$. subcapitata, S. spinosus, and $S$. acuminatus grown in the synthetic culture medium Chu-12

\begin{tabular}{llccc}
\hline Fatty acid & & P. subcapitata & S. spinosus & S. acuminatus \\
\hline C14:0 & Myristic acid & $3.36 \pm 0.01$ & n.d. & $9.26 \pm 1.25$ \\
C15:1 & Cis-10-pentadecanoic acid & $5.73 \pm 0.10$ & n.d. & $15.88 \pm 2.17$ \\
C16:0 & Palmitic acid & $21.79 \pm 0.94$ & $45.70 \pm 3.21$ & $23.25 \pm 2.05$ \\
C16:1 & Palmitoleic acid & $6.32 \pm 0.33$ & $6.51 \pm 0.56$ & $4.83 \pm 0.43$ \\
C18:1 & Oleic acid & $28.83 \pm 1.00$ & $17.95 \pm 0.10$ & $11.37 \pm 0.48$ \\
C18:1 t-11 & Vaccenic acid & $5.76 \pm 0.74$ & n.d. & $4.37 \pm 0.48$ \\
C18:2 n-6c & Linoleic acid & $13.83 \pm 0.60$ & $10.48 \pm 0.40$ & $8.98 \pm 1.02$ \\
C18:3 & Alpha-linolenic acid & $10.63 \pm 0.62$ & $19.35 \pm 0.93$ & $22.06 \pm 2.21$ \\
C20:5 n-3 & Eicosapentaenoic acid & $3.75 \pm 0.22$ & n.d. & n.d. \\
PUFA & Polyunsaturated fatty acids & 28.21 & 29.83 & 31.04 \\
MUFA & Monounsaturated fatty acids & 46.64 & 24.46 & 36.45 \\
SFA & Saturated fatty acids & 25.15 & 45.70 & 32.25 \\
Pigment & & P. subcapitata & S. spinosus & S. acuminatus \\
Chl-a & Chlorophyll a & $3.55 \pm 0.86$ & $2.93 \pm 0.56$ & $5.25 \pm 0.23$ \\
Chl-b & Chlorophyll b & $1.35 \pm 0.35$ & $1.15 \pm 0.16$ & $0.81 \pm 0.18$ \\
Ct & Carotenoids & $0.26 \pm 0.01$ & $0.30 \pm 0.02$ & $1.02 \pm 0.02$ \\
\hline
\end{tabular}

n.d.: not detected 
In most organisms, fatty acids contain among 12 and 22 carbon atoms, with palmitic acid being the main compound, followed by oleic acid and then by other fatty acids typical of each species (REZANKA \& SIGLER, 2009). The same behaviour was identified in this study (Table 3). NASCIMENTO and co-workers (2013) reported oleic acid as the main fatty acid in terms of concentration for $P$. subcapitata and palmitic acid for the genus Scenedesmus when evaluating 12 microalgae strains. Our results are in accordance with this study (Table 3).

All species studied here presented fatty acids of the $\omega-3$ series, with the highest concentration obtained for S. acuminatus (22\%, Table 3) in an ethereal extract of $19 \%$ (Table 2 ). Microalgae naturally contain $\omega-3$ fatty acids, which can be purified to provide a high value food supplement. Due to the benefits to human health, studies have been carried out for obtaining and extracting this fatty acid from microalgae species (HARUN et al., 2010).

The composition of fatty acids determines the quality of the biofuel (NASCIMENTO et al., 2013). The most important characteristics affecting properties are the length of the carbon chain and the number of double bonds. The monounsaturated fatty acid (MUFA) and saturated fatty acid (SFA) fractions of the raw material are related to the properties of the biofuel, and an optimal raw material should contain higher concentrations of C16:1 and C18:1. Fuels rich in these FAMEs will have adequate cetane number, cold-flow parameters, and viscosities (StANSELl et al., 2012). Regarding this analysis, the species $P$. subcapitata presented better results (Table 3 ), but its productivity in ethereal extract was the lowest compared to the other species studied $\left(0.005 \mathrm{~g} \mathrm{l}^{-1}\right.$ day $\left.^{-1}\right)$ (Table 1$)$.

Odd chain fatty acids are rare. The presence of C15:1 was detected in two species $(P$. subcapitata, 5.7\%, S. acuminatus, 15.9\%) (Table 3). High molecular weight lipids containing odd fatty acids have already been isolated from Scenedesmus spp. (ReZANKA \& SigLer, 2009). For Scenedesmus abundans, C15:0 and C17:0 were found (RAI \& GUPTA, 2017). In another study, four different odd fatty acids (C15:0, C15:1, C17:0, and C17:1) were obtained from Scenedesmus sp. cultivations (DHuP et al., 2016). However, in all these reports the concentration of these acids was always inferior in relation to the other fatty acids. Differently, C15:1 was the third main fatty acid identified for S. acuminatus $(15.88 \%)$ (Table 3$)$.

A study on the effect of nitrogen source on the accumulation of lipids by two species of microalgae (Scenedesmus abundans and Chlorella ellipsoidea) showed that by changing the nitrogen source only, the fatty acid profile could be altered. For both of these species, the alteration resulted in the production of C15:1 (GonZÁLEZ-GARCINUÑo et al., 2014). Thus, the nitrogen sources present in the Chu-12 medium may have stimulated the synthesis of C15:1 in P. subcapitata and S. acuminatus, too.

The profile of fatty acids produced by microalgae is dependent not only on the species, but also on extrinsic factors, e.g. nutrient concentration, $\mathrm{pH}$, light intensity (STANSELL et al., 2012). Thus, the conditions offered here may have stimulated this increased production of C15:1 by $S$. acuminatus. The odd-chain fatty acids (C15:0 and C17:0) have been shown to be associated with human diseases, e.g. multiple sclerosis and Alzheimer's disease (JENKINS et al., 2015). Thus, S. acuminatus could become a potential supplier of odd chain fatty acids to the human diet.

According to the data presented on chlorophyll and carotenoid contents, S. acuminatus species presented higher concentrations of chlorophyll-a $\left(5.25 \mathrm{mg} \mathrm{l}^{-1}\right)$ and carotenoids (1.02 $\mathrm{mg}^{-1}$ ) (Table 3). It was observed that even species of the same genus, in this case of genus Scenedesmus, pigment contents were found very different. S. acuminatus presented higher concentration of pigments, which was expected as it also presented higher fat content, and the pigments are contained in the lipid fraction of the cells (Soтo et al., 2011). 


\section{Conclusions}

Each of the three microalgae species studied demonstrated different potential for the products of their metabolisms: S. spinosus presented faster growth and high protein content, $P$. subcapitata presented the highest content of lipids extracted, and $S$. acuminatus showed increased production of chlorophyll and carotenoid pigments. All produced fatty acids of the $\omega-3$ series. These differences in terms of potential might be applied to obtain different products in optimized concentrations.

The authors gratefully acknowledge the Brazilian research funding agencies CNPq and FUNDECT for their financial support. We also thank Dagon Manoel Ribeiro for the skilled assistance with the fatty acid analyses. The authors declare no conflict of interest.

\section{References}

Adeyemi, N.A., Mohiuddin, A.K.M. \& Jameel, A.T. (2011): Biodiesel production: a mini review. Int. Energ. J., 12, $15-28$.

AOAC (2000): Association of Official Analytical Chemists. Washington, DC, USA.

AOCS (2005): Official procedure. Approved procedure Ce 1-62 - Fatty acid composition by gas chromatography. American Oil Chemists Society.

Bligh, E.G. \& Dyer, J.W. (1959): A rapid method of total lipid extraction and purification. Can. J. Biochem. Phys., 37, 911-917.

Cô̂lho, D.F., Tundisi, L.L., Cerqueira, K.S., Rodrigues, J.R.S., Mazzola, P.G., Tambourgi, E.B. \& Souza, R.R. (2019): Microalgae: Cultivation aspects and bioactive compounds. Braz. Arch. Biol. Techn., 62, e19180343.

Dhup, S., Kannank, D.C. \& Dhawan, V. (2016): Understanding urea assimilation and its effect on lipid production and fatty acid composition of Scenedesmus sp. SOJ Biochem., 2, 1-7.

González-Garcinuño, A., Tabernero, A., SÁnches-Álvarez, J.M., Del Valle, E.M.M. \& Galán, M.A. (2014): Effect of nitrogen source on growth and lipid accumulation in Scenedesmus abundans and Chlorella ellipsoidea. Bioresour. Technol., 173, 334-341.

Harun, R., Singh, M., Forde, G.M. \& Danquahd, M.K. (2010): Bioprocess engineering of microalgae to produce a variety of consumer products. Renew. Sust. Energ. Rev., 14, 1037-1047.

Jenkins, B., West, J.A. \& Koulman, A. (2015): A review of odd-chain fatty acid metabolism and the role of pentadecanoic acid (C15:0) and heptadecanoic acid (C17:0) in health and disease. Molecules, 20, 2425-2444.

Kiss, B. \& NÉmeth, Á. (2019): High-throughput microalgae cultivation with adjustable led-module applying different colours for Nannochloropsis and Chlorella microcultures. Acta Alimentaria, 48, 115-124.

LeE, Y. \& Shen, H. (2004): Basic culturing techniques. -in: Richmond. A (Ed.) Handbook of microalgal culture: Biotechnology and applied phycology. Blackwell Publishing 1, pp. 40-56.

LichtenthaleR, H.K. \& Wellburn, A.R. (1983): Determinations of total carotenoids and chlorophylls a and b of leaf extracts in different solvents. Biochem Soc. T., 11, 591-592.

Minillo, A., Godoy, H.C. \& FonseCA, G.G. (2013): Growth performance of microalgae exposed to $\mathrm{CO}_{2}$. J. Clean Energ. Technol., 2, 110-114.

Musharraf, S.G., Ahamed, A.M., Zehra, N., Kabir, N., Choudhary, M.I. \& Rahmas, A. (2012): Biodiesel production from microalgal isolates of southern Pakistan and quantification of FAMEs by GC-MS/MS analysis. Chem. Cent. J., 6, 1-10.

Nascimento, I.A., Marques, S.S.I., Cabanelas, I.T.D., Pereira, A.S., Druzin, J.N., ... \& Nascimento, M.A. (2013): Screening microalgae strains for biodiesel production: lipid productivity and estimation of fuel quality based on fatty acids profiles as selective criteria. Bioenerg. Res., 6, 1-13.

Pereira, C.M.P., Hobuss, C.B., Maciel, J.V., Ferreira, L.R., Pino, F.B.D. \& Mesko, M.F. (2012): Biodiesel derived from microalgae: advances and perspectives. Quím. Nova, 35, 2013-2018.

RAI, M.P. \& GUPTA, S. (2017): Effect of media composition and light supply on biomass, lipid content and FAME profile for quality biofuel production from Scenedesmus abundans. Energ. Convers. Manage., 141, 85-92. 
RezanKa, T. \& Sigler, K. (2009): Odd-numbered very-long-chain fatty acids from the microbial, animal and plant kingdoms. Progr. Lipid Res., 48, 206-238.

Ribeiro, D.M., Zanetti, G.T., Juliao, M.H.M., Masetto, T.E., Gelinski, J.M.L.N. \& Fonseca, G.G. (2019): Effect of different culture media on growth of Chlorella sorokiniana and the influence of microalgal effluents on the germination of lettuce seeds. $J A B B, 7,6-10$.

Sipaúba-Tavares, L.H., Pelicioni, L.C. \& Oliveira, A. (1999): Use of inorganic (NPK) and the CHU12 medium for cultivation of Ankistrodesmus gracilis in laboratory. Braz. J. Ecol., 1, 10-15.

Soto, P., Gaete, H. \& Hidalgo, M.H. (2011): Assessment of catalase activity, lipid peroxidation, chlorophyll- $a$, and growth rate in the freshwater green algae Pseudokirchneriella subcapitata exposed to copper and zinc. Lat. Am. J. Aquat. Res., 39, 280-285.

Stansell, G.R., Gray, V.M. \& Sym, S.D. (2012): Microalgal fatty acid composition: implications for biodiesel quality. J. Appl. Phycol., 24, 791-801. 